This is a self-archived version of an original article. This version may differ from the original in pagination and typographic details.

Author(s): Kaasik-Krogerus, Sigrid

Title: Identity politics of the promotional videos of the European Heritage Label

Year: 2020

Version: Accepted version (Final draft)

Copyright: (C) 2019 Informa UK Limited, trading as Taylor \& Francis Group

Rights: In Copyright

Rights url: http://rightsstatements.org/page/lnC/1.0/?language=en

Please cite the original version:

Kaasik-Krogerus, S. (2020). Identity politics of the promotional videos of the European Heritage Label. Contemporary Politics, 26(1), 1-16. https://doi.org/10.1080/13569775.2019.1611207 


\section{Identity Politics of the promotional Videos of the European Heritage Label}

During past decades, the EU has responded to a variety of 'crises' by promoting a common cultural heritage to advance European identity and belonging. This article analyses identity politics conducted in the framework of the EU's flagship heritage action, the European Heritage Label. I borrow from 'banal nationalism' to scrutinise the usage of 'we' and 'us' in the promotional videos of the European Heritage Label sites as subject positions offered for identification in this heritage discourse. Analysis shows that the subject positions are constituted by emphasis on the national level, preservation of the past for future generations and the key role of experts in the process of heritage. Although the heritage agents talk about Europe (representation) they do not identify with that as 'us'. By making the lack of 'banal Europeanness' in the videos visible the article shows the ambiguities of European identity politics.

Keywords: identity politics; heritage; European Heritage Label; European Union; discourse; identification

\section{Introduction}

European integration exemplifies well the claim that identity and belonging become real in the context of a crisis. The breakdown of the Bretton Woods monetary system that shook the confidence of the European Community in the 1970s was followed by the Declaration on European Identity (1973) aimed at defining Europe's place in the world (Karlsson, 2010, p. 39). Ever since then identity politics has played an important role in tackling various crises, the most recent ones being the 'Euro crisis' followed by the economic recession and the rapid increase in the number of people seeking refuge in Europe, mapped as a 'refugee crisis'. In this context identity questions like whether or not the euro has undermined 'our' economic stability and who does or does not belong to Europe, have been widely debated in national and European level political arenas and in public, often in relation to European cultural heritage. 
From a communicative perspective, crisis is first and foremost a discursive act of mapping certain things as 'crisis' - a moment when, on the basis of common problems, decisions or choices should be made concerning living together in the future (Hepp, Elsler, Lingenberg, Mollen, Möller \& Offerhaus, 2016). Since heritage is seen to have the potential to create a dialogic space for increasing social cohesion and enhancing belonging (for example, Harrison, 2013), it fits well with advancing the 'conversation' needed for tackling the crises (see also Lähdesmäki, 2017). Furthermore, European cultural heritage is one of the key 'building blocks' in constructing EU identity narratives. The importance of common heritage was pointed out in the Declaration on European Identity in 1973 (see also Burgess, 2002, p. 479). Since then, the amount and scope of EU heritage policy documents has increased enormously (Delanty, 2005; Sassatelli, 2008; Lähdesmäki \& Mäkinen 2019, pp. 36-37). The most recent example of EU heritage policy, the EU flagship heritage scheme-European Heritage Label (EHL), in which 25 member states currently participate-was initiated by the European Commission (EC) in 2011.

In the framework of critical heritage studies heritage is not a not thing but a cultural and discursive process of mediating historical narratives, collective memories and related values (Dicks, 2000; Smith, 2006, p. 2; Waterton \& Smith, 2009, pp. 12, 15-16). Therefore, the EU's intensifying heritage policy, including the launch of the EHL, as well as European Year of Cultural Heritage 2018, can be interpreted as acts of doing heritage (Dicks, 2000; Waterton \& Smith, 2009, pp. 12, 15-16). Against this background it is not surprising that instead of homogeneity, the 'cultural heritage' of Europe is mapped as a battlefield of cultural images confronting cultural traditions that have shaped Europe (Eder, 2009, p. 436; Jones \& Subotić, 2011). To capture that process, I approach European cultural heritage as a discourse, a system of meanings and 
the social practice of meaning giving, i.e. doing things (Raik, 2003, pp. 27-28; see also Fairclough, 1995, p. 2; Kaasik-Krogerus, 2016, p. 16; Waterton \& Smith, 2009, p. 13). Hence, heritage discourse is not only related to or used in but is identity politics, a practice of influencing other people (cf. Mouffe, 2005). This practice exploits cultural belongings with the aim of constructing Europe as a distinctive political, cultural and economic entity that enables people to identify themselves as Europeans and feel a sense of belonging to Europe (Sassatelli, 2002, p. 436; Kohli, 2000, p. 118). While scholars have analysed the construction of European heritage to find out about the narratives formed and the affects related to EU identity politics (for example, Lähdesmäki, 2017), this article focuses on identification, as despite its importance, less attention has been given to this.

Identity and belonging as complementary but not synonymous concepts are entangled in the heritage discourse. The key articulations of identity are found in the stories of who we think we are, whereas belonging is related to the questions of inclusion and exclusion. While identity involves individual and collective narratives of self and other, labelling and myths of origin and destiny, belonging is about experiences of access and participation (Anthias, 2008, p. 8). This article focuses on the 'banal' (Billig, 1995) level as a connecting link between identity as narratives and belonging as a sense of identification with these narratives. I analyse how heritage agents use the deixes 'us', 'we' and 'our' in the EHL promotional videos and form subject positions of heritage discourse by simultaneously taking these positions and engaging and inviting the audience to identify (cf. Kantner, 2006, pp. 509-515). In this way I am responding to the criticism concerning the lack of human agency in Billig's work by bringing the idea of banality together with a human agency (see also Fox \& Miller-Idriss, 2008; Antonsich, 2016, pp. 33-34). Simultaneously the deixes used in the videos are an 
example of what Billig (1995) calls 'forgotten reminders' (p. 38), widely used in daily conversations and the media. As Billig writes, the reminders hardly register in the flow of attention and this makes them powerful. Consequently, analysing these positions makes an opaque form of power visible (cf. Foucault, 1981, p. 86).

The promotional videos of the EHL sites that form the empirical data for this article are available at the EC webpage. The focus of the EHL is on promotion and communication of 'European significance' of the sites (vis-à-vis preservation of the heritage): the designated sites are supposed to promote their European dimension and to bring to life European narrative (EC, 2010, p. 2; EP, 2011, p. 3; EC, 2018). The EHL website forms an important tool of this process. The videos show how the site representatives as the ones who put the EHL into practice on a daily basis, engage with and identify themselves with the EHL on a banal level while introducing their sites in the videos. I ask from which subject position these 'messages' are told, which communities are 'imagined' in this process and what does this convey about the heritage discourse, as well as identity politics, conducted in the context of the EHL?

The videos also create possibilities for identification to the viewers of the promotional videos. . Indeed, a strong affective dimension of the videos that are supposed to contribute to people's sense of belonging to Europe (EC, 2018), is seen to reinforce their 'message' (Lähdesmäki, 2017). However, since it is problematic to draw conclusions about the audience (how visitors relate to the videos) on the basis of the media analysis (see Madianou, 2005; Kaasik-Krogerus, 2016), the reception is out of the scope of this study.

The article starts with a theoretical elaboration of the concepts of discourse, heritage and identity politics. It continues with an overview of methods, data and an empirical analysis, followed by the discussion and conclusions. 


\section{The Identity Politics of the European Heritage Label}

I understand discourse as a system of meanings and the social practice of meaning giving where power is used to constitute reality (Fairclough, 2001, p. 33). To elaborate the identity politics of the EHL, an analytical distinction is made between these two sides. First, as a system of meanings, heritage discourse forms a basis for a narrative template of identity politics. Second, as a social practice of meaning giving the focus shifts to the videos as a type of media that bring identity narrative to life and can simultaneously evoke a sense of belonging. As a link between these two, 'banal' tools of identification are scrutinised.

The narrative template is achieved by interlinking discrete events into a meaningful history (Bhabha, 1990). The evidence used in this process is (partly) truthful, however somewhat distorted, since narratives are plotted in a way in which life is not (Trouillot, 1995, p. 6). For instance, the idea of a common European memory built on the understanding of a shared European heritage is an example of an ongoing narrative operation (Lähdesmäki, 2014; see also Scalise, 2015). While heritage is done on the basis of the past, ranking the past events and narrating the past, as well as depicting 'us' as a unified group moving through history, is a present phenomenon targeted towards shaping the future (Harrison, 2013). In this process 'we' is not an autonomous actor but conditioned by subject positions from which communication takes place in the discursive context (Foucault, 1991, p. 58; Diez, 1999, p. 603; see also Ifversen, 2002, p. 4).

Coming to the second aspect, the social practice of meaning giving, the focus shifts to the media where the narratives are brought to life in the process of engagement. In connection with 'imagining' nations as communities (Anderson, 2006) as well as daily identity politics to maintain existing communities (nations) (for example, Edensor, 2002) the importance of legacy mass media has been depicted as not directly applicable 
to the introductory videos. In the context of maintenance, Michael Billig (1995) points out how media constructs a daily chronicle of the nation by using 'us' and 'here' in the texts as references to the nation and its territory (Billig, 1995, pp. 93-127). Critics of Billig have noted that there is no default correlation between 'us' and a nation since 'us' can also refer to a local or regional level (for example, Rosie, Petersoo, MacInnes, Condor \& Kennedy, 2006) and a national 'us' can be highly differentiated (Antonsich, 2016, p. 40). Paradoxically, the criticism confirms the idea of 'us' as a forgotten reminding of (diverse) communities: different 'story tellers' identify themselves with 'us' and simultaneously offer their audience a possibility for identification (see also Hepp et al., 2016, pp. 87-93). This takes place at various levels reaching from a local to a cosmopolitan one (Alasuutari, 2013; Beck, 2004; Antonsich, 2016, p. 32). It is important to keep in mind that the media contribute to creating a common communicative space (Schlesinger, 2000; Madianou, 2005, pp. 56, 73-74) where particular phraseology is made available to the people for thinking and talking about issues. At the same time, it is misleading to assume that people necessarily adopt the views or positions presented in the media (Madianou, 2005, pp. 15, 17, 129).

Although the EHL videos form a media for European identity politics, no direct parallels can be drawn between the videos and national mass media. While the (national) mass media updates its content daily on the basis of new topical issues, the same site videos are available 24/7 on the Internet with the aim of introducing the EHL sites and legitimising this heritage as 'European'. Also, compared to the national mass media, the question about who watches the videos is clearly more complex, not least because the videos are available in English. Last but not least, the location of the videos indicates European identity politics, since they are available on the EC website Creative Europe, the only public forum for the EU to communicate cultural meanings related to 
Europe (Lähdesmäki, 2017, p. 712). However-coming back to the system of meanings aspect - the content of the videos is produced in cooperation with the EHL sites situated in 18 different member states (cf. Scalise, 2015, p. 594). Thus, identity politics is performed and the community(ies) are imagined in an interplay between a variety of heritage agents who speak from the positions of 'us' and simultaneously make available certain phraseology related to the positions.

These positions make the role of the agency visible in heritage discourse and bring together representation and social practice. For example, Fairclough has criticised the Foucauldian approach for placing too much emphasis on representation and too little on social practice, in which actors are able to establish their visions and interpretations as right by exercising power (Fairclough, 2003, pp. 28-29, 33-34, 36). This is, however, done from subject positions that are made available in the discursive context. In this article deixes are analysed as the subject positions of the heritage discourse that are crucial for identification: instead of talking about 'us' and 'you and them' the question is about talking as 'us' (and to 'us' or 'you and them'). Variety in subject positions indicates a variety of communities 'imagined' as a result of the identity politics.

\section{Data and Methods}

My empirical data consists of 38 promotional EHL site videos whereas the actual heritage sites remain out of the scope of this study. The videos that last between three and four minutes each, were produced since the first EHL selection in 2013 until 2018, the last selection round up to now. In all of the videos there is at least one 'story teller' who introduces the site. At the end of each video the meaning of the EHL label for the site is elaborated. Most of the images focus on the sites, occasionally zooming in on old objects, documents, maps etc. as well as on story tellers. The videos also show the 
visitors, mostly children and young people. Sixteen videos are fully or partly in English, the rest are in various national languages and have English subtitles (including the videos of all the sites that were awarded in 2017) (see also Lähdesmäki, 2017).

Voice and image support and complement to each other in the videos: apart from talking as 'us', images show 'us', often in a symbolic manner (for instance, talking in the name of a nation and showing national flag). I stem from an understanding that there is no single or a right way to interpret visual data, since depending on the contexts images carry various meanings (Hall, 1997, pp. 228-232; see also Gillian, 2016, pp. 1622). In accordance with the research setting of this article, both voice and image are analysed in the framework of banal nationalism. The analysis started from transcribing the voice and the images of the videos. In the next phase, I focused on the parts of the transcription where 'us', 'we' or 'our' were used in the text (voice) and images (e.g. flags and bearings).

Critical discourse analysis enabled me to analyse 'us' as a subject position that makes possible both the identification of the speakers as well as the relationship between the speakers and their potential audience (Fairclough, 2001, pp. 31-32). Fairclough refers to 'ideal audiences' (Fairclough, 1995, p. 40) constructed in the discourses: if people are daily obliged to occupy the subject position of consumer, they will probably become consumers (Fairclough, 2001, pp. 171-172). The EHL videos enable me to analyse the positions taken in the videos whereas conclusions can be drawn about the positions offered to the audience but not necessarily taken by them.

\section{Results: three Communities of Authorised Heritage Discourse}

The analysis of the EHL videos shows that subject positions indicate three partly overlapping and complementary communities: contemporary, national and professional community. Contemporary community is imagined in an interplay between current 'us', 
the people from the past and people in the future. National community is imagined in relation to other nations or other spatial scales like regions or Europe. Last but not least, professional community aims at educating non-professionals (those visiting the site or watching the video). While professional community was imagined in all videos, other two positions were not taken in every video.

Although all the videos emphasise 'European significance' of the sites, no subject positions are taken in the videos that would enable the actors to form European community. Hence, the videos create an ambiguous setting where European significance of the sites as well as Europe in general form key topics of the videos but actors hardly engage with these on a banal level as 'us'.

The subject positions come together and very well expose the phenomenon that has been coined as 'authorised heritage discourse' (AHD) by Laurajane Smith (2006). As Smith writes, grand national narratives and technical heritage expertise are constitutive to the AHD. Heritage is seen as positive and fragile, so contemporary generations are supposed to take care of and leave it unchanged for future generations (Smith, 2012). Those entitled to take responsibility in this process are 'experts' who are supposed to protect and safeguard heritage as well as speak about it (Smith, 2006, p. 12). The EHL videos illustrate well Smith's (2006) claim that the innate value of heritage assumed by AHD contributes to the monovocality of heritage, where few speakers spread information to many recipients (p. 37). In most of the videos one or two professionals talk in the name of the site or location (managers, heads, directors, historians, curators, officials). However, as three communities imagined in the videos indicate, monovocal does not mean uniform. 


\section{Contemporary Community}

Contemporary community is based on the instructive past that is used selectively in the present for forming our future (Harrison, 2013; see also Petersson \& Hellström, 2003, p. 248). Respectively, the past and historical actors are treated as authorities capable of telling and reminding contemporary 'us' about various things. For instance, the Archdiocesan museum in Olomouc is characterised as a place which reminds 'us' of 'our' roots, in Christianity, Judaism and antiquity and points to 'our' European identity. Similarly, the representative of Athens tells that whenever 'we' trace 'our' origins 'we' come back to go to Greece and Athens, 'we' come to meet the philosophy of Plato and Socrates, the ideals of classical architecture and democracy (similar examples include the Abbey of Cluny, May 3, 1791 Constitution and the Peace Palace, Hague).

The scope of the past referred to in the videos is rather wide, from very distant to near history. As the representatives of the Archaeological Park Carnuntum explain,

even if it was 2000 years ago, it looks to us very actual /.../. Look at the Roman system of justice, it is the base for all modern justice systems, or look at the Latin language which is the basic of many, many European languages.

The value of the past is supported by the images that communicate respect towards old artefacts. Videos show maps, books, jewelry, personal property etc. that is handled with care: for instance, gloves are used to show the artefacts. Images show how the power of the past is intertwined with its fragility.

The more recent historical figures share their successful experiences in the videos by themselves. The messages they communicate are strengthened by close-up images. The organisers of the Pan European Picnic in Sopron in 1989 perform as 'us', who opened the gate that had been closed for 40 years, and enabled East Germans to cross the Austrian border. The leader of the Solidarity Movement in the Gdańsk 
Shipyard, who later became the President of Poland, Lech Walesa, tells viewers how 'we' showed that the biggest problems should be solved at the negotiating table in an intelligent way, using arguments rather than force. The example of Solidarity is similar to what Petersson and Hellström (2003) write about in the context of the Founding Fathers of the EU, like Robert Schuman: 'dead kings' guiding and helping 'us' to restore the golden age (pp. 237, 248). Indeed, Robert Schuman's claims from the 1940s are quoted in the Schuman's House video as relevant today as then: 'we must change the way we treat our enemies, because the enemy, Germany, has lost the war' and 'we will be allies, we will reach out to this nation and build relations'. To make identification easier and evoke sense of belonging, images of the video show Schuman's daily life — images of his house, interior and personal belongings.

The spatial dimension of the contemporary community varied a lot and was, in some cases, rather narrow, like the residents of Kaunas. As the representative of the city claims, together with the EHL, 'I' hope that 'we' will gain more self-confidence and have more pride in the city. In some other cases, the spatial dimension was rather wide, including Europe or even the world. For instance, the room in the Hotel de Ville in Strasbourg, where the first Committee of Ministers of the Council of Europe met in August 1949, is seen to be very dear to the hearts of all Europeans, since this is where the Europe, that 'we' know today, came into being (similar to Schuman's House, Maastricht Treaty and Village of Schengen). However, the Franja Partisan Hospital in Slovenia is an example of even wider identification: 'This is an opportunity for us to share these ideas and values. The message of the hospital will be passed on the people from different parts of Europe, may be not just Europe, also other parts of the world'. Apart from knowing and remembering things from the past, the need to understand these correctly is also emphasised. As a representative of the Museo Casa Alcide De 
Gasperi claims, 'we' remember De Gasperi as the father of the Italian Republic and one of the founding fathers of Europe, but 'we' cannot understand him unless 'we' actually go and see the place he came from and learn that De Gasperi was a son of a border region. By emphasising De Gasperi’s background, his political action becomes depoliticised: it can be viewed like a 'natural' outcome of his past that is not related to ideological choices. Learning from often romanticised past simultaneously communicates its superiority over current 'us': for instance, the values that the democracy of Athens incorporates are seen to 'even surpass our modernity'. The representative of the Archaeological Park Carnuntum tells that 'we' should not forget that ancient drama and theatre is one of the biggest inventions of European culture and 'we' were able to learn a lot from the Romans (similar to the Museo Casa Alcide De Gasperi and Mundaneum). A new relevance of the Charter of Law of Abolition of the Death Penalty is emphasised in the context of the current debate about terrorism: when 'we' discuss how to deal with terrorism, and with all the threats, 'we' must keep in mind that the death penalty is not the solution. While 'we' refers to subjects who participate in contemporary debates, it also shows the ambiguity of the subject positions. Contemporary people who participate in the debates about the death penalty might have different views but for being able to belong among 'us', a certain viewpoint and understanding is presumed (see also Anderson, 2006).

In summary, the logic of the past—mediated by heritage agents—-teaches 'us' what should be done to cope with the current crises and handle those in the future (cf. Petersson \& Hellström, 2003, p. 243). Due to its unknown character, the future can evoke both hopes and fears (see also Ahmed, 2004, pp. 183-184) and heritage, although itself preserved and safeguarded, is seen to offer a possibility to manage these. As a subject position, contemporary 'us' is first and foremost a temporal creature and in this 
sense wide, abstract and supposedly inclusive (cf. Waterton \& Watson, 2013, p. 551).

Some videos address (all of) 'us' who live in the contemporary world, and should learn from the past while being disengaged from the use of heritage (Waterton \& Smith, 2009 , p. 13). However, access to this community is not granted automatically but it is conditional: for belonging among 'us' people have to know what happened in the past, interpret it in a 'correct' way by accepting its supposed universality and draw 'proper' conclusions concerning the patterns of action in the present and the future (cf. Smith, 2006, pp. 99-100).

\section{National Community}

National community is constituted by an exceptional 'us': it can be unique, the first or just different or better than the others. Since the AHD is both constituted by and constitutive of the construction of national identity, this community is based on a strong inherent connection between the AHD and national values and identity (see Smith, 2006; Waterton \& Smith, 2009, p. 12).

The exceptionality of the national 'us' emphasised, for instance, by a representative of the Great Guild Hall who claims that in Estonia there are the most museums per person in Europe so 'we' are very museum friendly. Similarly, the site representative of Mundaneum tells that 'we' are here in the Mundaneum in Mons in Belgium, a true archive center (similar to the Museo Casa Alcide De Gasperi, Hambach Castle and Bois du Cazier). The difference is emphasised in the video of Kaunas from 1919-1940:

When Lithuania moved capital to Kaunas during twenty year we built not completely new city but we built quite a new city with a lot of new buildings, new functions, new monuments, new housing, we tried to invent architecture which is a bit different from Russian, from our past, and to create something new which is based on national identity. 
Both of the phrases 'true archive center' and 'new architecture based on national identity' communicate 'our' specialty.

The links created between presumed unique sites and the surrounding national context where 'we' are located, also makes the nation (states) special. Hence, national actors use a European format to emphasise their significance in the European context. A European framework is also communicated by the EHL logo at the beginning and end of each video (see also Lähdesmäki, 2017). As in the examples above, the relationship between national 'us' and Europe is usually depicted as a complementary one. However, unlike national community, Europe is based on representation, not identification (Maastricht Treaty and Village of Schengen as exceptions) (cf. De Cesari, 2017, p. 22). For instance, Sagres Promontory is characterised as a significant place in the history of Europe and the first place of the Portuguese discoveries: 'We are the most south west harbour of the Europe, here you cross from the Mediterranean to the Atlantic which is called Sagres Promontory, the place where first globalization began'.

National 'us' in voice is complemented by national languages. Also, some English language videos contain words in other languages. For instance, in the Historic Ensemble of the University of Tartu, the specialty of the festive hall is emphasised by using the Estonian term for the hall: 'The most important room in the main building is aula and it is a celebration hall where we have the highest guests, have guest lectures, the rectors are inaugurated in aula, the graduation ceremonies are traditionally held in aula.'.

Concerning images, national community is communicated by showing national flags, texts in national languages, (country) maps and bearings. Some videos stress the importance of the flags by zooming in and close up shots (for example, the Krapina Neanderthal Site, the Sagres Promontory, the General Library of the University of 
Coimbra, Kaunas from 1919-1940, the Imperial Palace in Vienna, Hambach Castle and the Great Guild Hall). Other videos show national (and sometimes the EU) flags hanging there as part of the general image (for example, the Historic Ensemble of the University of Tartu). These general images form an orthodox example of Billig's (1995) ‘forgotten reminding' where 'unwaved, unsaluted, unnoticed' flags hanging outside a public building or decorating a filling-station forecourt, convey the idea of a Europe of nations (p. 46; cf. Antonsich, 2016, p. 32). Similarly, both explicit and unnoticed images appeared in texts and signs written in national languages, national monuments (like the double-headed eagle of the Austrian Empire in the video of the Imperial Palace) and bearings.

In brief, the national narratives of Europe are embedded in the site videos to construct and enhance national communities (see also Scalise, 2015, p. 603). These communities, based on the national 'us', are situated within Europe and explained from the perspective of European significance in the EHL videos. Simultaneously, the videos indicate the different national 'readings' of Europe (see also Diez, 1999, p. 602; Jenkins, 2008, pp. 153-154). The videos show how Europe meshes into one's understanding of one's own (nation) state and therefore means different things to different sites (see also Risse, 2003, pp. 491, 501; Lähdesmäki \& Mäkinen, 2019). Ambiguity of the notion of Europe becomes explicit while some sites seek recognition for their location as 'European', others proudly emphasise their contribution to Europe.

\section{Professional Community}

In professional community a clear distinction is made between in most cases male professionals and various non-professionals: 'us' stands for professionals and 'them or you' for visitors and the wider audience who watch the EHL videos. In some videos professional 'us' is complemented by referring also to 'me' as a professional or an 
expert, often together with a close-up image. Thus, both the story teller and their institution are introduced by voice, as in the video of the National Archives of Torre do Tombo: 'My name is Silvestre de Almeida Lacerda, I am deputy general director for books, archives and libraries and director of Torre do Tombo, the National Archive.'. This setting, widely used in documentaries, increases the credibility and authenticity of the actors as trustworthy professionals.

Concerning the practice of professional community, a distinction between their mission and responsibility (as being), owning and managing collections (as having) and daily actions, like exhibiting artefacts, organising events and developing research programs (as doing), can be made. Being and having are based on temporal and spatial aspects - uniqueness and specialty in either or both historical and geographical or territorial terms. The words spoken by the director of the General Library of the University of Coimbra gives an example of temporal specialty: 'People often ask us to show them the oldest book we have. It is an illuminated bible produced in Strasbourg in the 12th century which is quite rare.' (there is also a similar example in the Archive of the Crown of Aragon). Spatial uniqueness is emphasised in the video that introduces the Imperial Palace in Vienna claiming that 'we' do have things of Europe-wide importance and both 'our' architecture and 'our' institutions serve as important examples of how peaceful developments have had a greater impact than military conflict. In the video of the General Library of the University of Coimbra temporal and spatial specialty are combined in a statement that 'our' library has one of the most beautiful library buildings in the world and the collections from the 12th century onwards allow us to differentiate 'ourselves' from other libraries (similar claims are also made in the site videos of the Historic Ensemble of the University of Tartu and Krapina Neanderthal Site). 
In the case of doing, the story tellers emphasise 'our' action. Action can stand for the physical construction and improvement of the site, like in the Archive of the Crown of Aragon, the Archaeological Park Carnuntum, Sagres Promontory, the Peace Palace in Hague and Robert Schuman's House. More often, however, daily action and events organised on the sites are pointed out: a festival of art that focuses on Greek drama in Carnuntum, a new exhibition at the Great Guild Hall, the permanent exhibition of the Hambach Festival and the unique educational experience, as well as 500 great public open concerts and approximately 1,000 smaller concerts per year (Liszt Academy). Action can also be based on cooperation between professional 'us' and the other EHL sites. As a representative of Athens claims, being awarded the EHL 'we' hope to develop synergies with other European countries (in a similar way to the Great Guild Hall, the Archive of the Crown of Aragon and Charter of Law of Abolition of the Death Penalty). In temporal terms, action is characterised as continuity from the past to the contemporary community. In the Olomouc Premyslid Castle the medieval period is exposed underground whereas, as the story teller explains, on the first floor 'we' exhibit the Olomouc treasure linked to selected churches (in a similar way to Robert Schuman's House).

While professional 'us' explain and arrange things, their audience is expected to engage with this community by listening, understanding and participating. Thus, this community offers a good example of how gendered expert lead AHD addresses heritage visitors as receivers of knowledge provided by various experts (Smith, 2006, pp. 33-34; Smith, 2008, p. 173; Reading, 2014, pp. 401-403). As the representative of the Peace Palace in Hague tells, 'we' felt that 'we' should have a visitor center to explain this story of peace buildings. 
A common image in the videos is mostly male site professional, often the story teller showing some object or explaining something to a group of visitors. Depending on the video the visitors are either shown to be listening — and, on the basis of close up images, also concentrating on the story_-or some elements of interactive learning are included. For example, in the Olomouc Premyslid Castle and the Archdiocesan Museum videos children draw and do some physical exercises. Images also show people who use computers and interactive tools.

Apart from showing the images of the audience, an ideal audience is mapped vocally. One of the targets is to reach as wide an audience as possible. As a representative of the Olomouc Premyslid Castle puts it, 'we' have a clear plan for reaching all age groups from pre-schoolers to senior citizens. The European District of Strasbourg wants to use Lieu d'Europe to introduce the public to the peculiarity that the city is the seat of both European Union institutions as well as the Council of Europe (47 member states). Similarly, the archeological sites of Athens prepare educational activities for all possible target groups, as in 'this way we hope that we disseminate these values that are at the core of the European identity'. In parallel, the importance of children and young people as a target group, in accordance with the goals of the EHL, is depicted both in voice and image (for example the Liszt Ferenc Academy of Music and the Museo Casa Alcide De Gasperi and Javorca Church). This contributes to the teacher-learner setting where those teaching and passing it on to future generations are older (and presumably wiser) than those who are supposed to learn. The setting follows similar logic with the contemporary community, since the (past) knowledge is mediated to the future. Both positive and negative legitimation is demonstrated. While positive legitimation emphasises why sites have to be cherished and inspired, negative legitimation often focuses on very tragic events and occurrences to steer away from and 
avoid repeating (Vendil, 2000; see also Petersson \& Hellström, 2003, p. 238; Kohli, 2000, pp. 127-128).

While in general the professional community is based on a clear distinction between 'us' (as mostly male professionals) and 'you or them' (mostly visitors and audience) some videos create presence effects that blur the boundaries between professional 'us' and their audience and these effects give the audience the possibility to identify with the sites as part of 'us' (a rather unclear community). As the Lord Mayor of Münster addresses the audience, 'we' are here in a very interesting building and the very important famous gothic building 'our' city hall and especially 'we' are here in the chamber of the council where in 1645 they began the negotiations between the states of the 30-year war. Similar inclusive tools that address visitors as 'us' and not 'you' or 'them' are also used in some videos like Osnabrück, Liszt Ferenc Academy of Music, Krapina Neanderthal Site, the European District of Strasbourg, Rodzinski Palace, the Archive of the Crown of Aragon and Leipzig's Musical Heritage Sites.

\section{Discussion and Conclusions}

Critical heritage studies challenge the expert lead static AHD by emphasising the contested uses of the past in making various voicings of heritage hearable and consequently advancing the dialogic space for increasing social cohesion and belonging (Harrison, 2013; Kisić, 2017). Therefore, it is understandable to base identity politics on the dialogic potential of the European heritage discourse as common ground that would contribute to overcoming the 'crises' of Europe. In this process representations of heritage are entangled with the subject positions offered for identification. As the current research shows, actors who create representations of Europe in relation to forming European heritage in the videos that follow more or less the same template do 
not necessarily explicitly identify themselves with these representations on a 'banal' level as 'Europeans'.

As Michael Billig (1995) writes, banality indicates the strength of national symbols and practices and therefore has key importance in the mundane renewal of power relations. This article shows the strength of the professional, contemporary and national 'us' as subject positions characteristic to the AHD as a national phenomenon. This strength is interwoven with the absence of 'us' as Europeans and, related to this, to Europe as a community (cf. De Cesari, 2017, pp. 22, 31). The question is not about a conscious attempt to 'promote' national or professional community in the European forum. Rather the actors routinely identify themselves as members of the professional, contemporary and national community, whereas it is unconventional to use the same pattern in the case of Europe (cf. Cram, 2009). At the banal level-the level most taken for granted-agents speak about Europe as representatives of the EHL site from the subject positions related to national communities. Europe is represented in the videos as a cultural meaning system and an idea (see also Kohli, 2000, pp. 199-122). While talking about Europe, most of the story tellers do not identify themselves as representatives of Europe and seldom address their audience as such. The future imaginaries are tightly related to Europe but this is not mediated as the future of Europeans.

The process can be interpreted in two ways, as both complementary and contradictory. On the one hand, the study shows that one may take part in EU identity politics and thereby contribute to European cultural integration without identifying with Europe (see also Medrano \& Gutiérrez, 2001, p. 755; Risse, 2003, p. 489; Delanty, 2005, p. 18). In parallel, national, professional and contemporary communities are imagined as complementary 'by-products' of the same identity politics. Therefore, the 
politics reinforces the position of both national and professional (heritage) communities. On the other hand, the results can be interpreted as an invisible struggle over the ownership of heritage where implicit maintenance of 'our' heritage is intertwined with the explicit construction of a 'European' heritage. While the EHL is aimed first and foremost at promotion and communication (instead of preservation) of European heritage, the results indicate shortcomings of top-down identity politics. Videos make European significance of the sites explicit and contribute to forming 'European' heritage by creating European narratives of the sites. At the same time the results show that on a banal level, 'us' as heritage agents does not refer to 'us' as Europeans: site representatives talk aboutEurope and in the name of Europe but do not engage with Europe at the banal level. In sum, manufacturing a sense of engagement is clearly more difficult than creating common narratives, particularly since a great variety and substantial pluralism present also in the videos make the notion of European cultural heritage anything but clear concept (see also Lähdesmäki \& Mäkinen, 2019, p. 37).

While the heritage agents identify themselves with three communities, they simultaneously offer subject positions to the audience. Communication is monovocal, since agents talk to the audience but not with them. The subject positions indicate AHD, including a national approach, the key role given to mostly male heritage professionals (vis-à-vis an audience who are 'educated'), fragility of heritage and accordingly a need to safeguard, promote and save it for future generations (Waterton \& Smith, 2009, p. 13). However, the videos as a media are European, i.e. they are accessible via the EC website and include the EHL symbols. The analysis gives an example of how European heritage discourse is 'under construction' as AHD-in-the-making where explicit representation of Europe is not complemented by identification with Europe. This shows unintended ambiguity of EU identity politics. EU identity politics and the EHL 
as part of that emphasise the importance of advancing people's sense of belonging to Europe, and, as the videos show, do this by narrating Europe and the EU.

Simultaneously, there is no uniform link between promoting European heritage and contributing to the European citizens' sense of belonging of (see also De Cesari, 2017; Levitt, 2015; Ang, 2017), not least because of promoting authorised heritage instead of a dialogic space.

\section{Acknowledgements}

This work was supported by the European Research Council (ERC) under the EU's Horizon 2020 research and innovation program under Grant 636177 (EUROHERIT)

\section{Disclosure statement}

No potential conflict of interest was reported by the author.

\section{References}

Ahmed, S. (2004). The Cultural Politics of Emotion. London: Routledge.

Alasuutari, P. (2013). Spreading global models and enhancing banal localism. International Journal of Cultural Policy, 19(1), 103-119.

Anderson, B. (2006). Imagined Communities. Reflections on the Origin and Spread of Nationalism (2nd ed.). London and New York: Verso.

Ang, I. (2017). What are museums for? The enduring friction between nationalism and cosmopolitanism. Identities, 24(1), 1-5.

Anthias, F. (2008). Thinking through the lens of translocational positionality: an intersectionality frame for understanding identity and belonging. Translocations: Migration and Social Change, 4(1), 5-20.

Antonsich, M. (2016). The ‘everyday' of banal nationalism e Ordinary people's views on Italy and Italian. Political Geography 54, 32-42.

Beck, U. (2004). Cosmopolitical realism: on the distinction between cosmopolitanism in philosophy and the social sciences. Global Networks, 4, 131-156. 
Bhabha, H. K. (1990). DissemiNation: time, narrative, and the margins of modern nation. In H. K. Bhabha (Ed.), Nation and Narration (pp. 291-322). London and New York: Routledge.

Billig. M. (1995). Banal Nationalism. London: Sage Publications.

Burgess, P. J. (2002). What's so European about the European Union? Legitimacy between Institution and Identity. European Journal of Social Theory, 5(4), 467481.

Cram, L. (2009). Introduction: Banal Europeanism: European Union identity and national identities in synergy. Nations and Nationalism, 15(1), 101-108.

De Cesari, C. (2017). Museums of Europe: Tangles of Memory, Borders, and Race. Museum Anthropology 40, 18-35.

Delanty, G. (2005). What does it mean to be a 'European'?, Innovation: The European Journal of Social Science Research, 18(1), 11-22.

Dicks, B. (2000). Heritage, Place and Community. Cardiff: University of Wales press.

Diez, T. (1999). Speaking 'Europe': the politics of integration discourse. Journal of European Public Policy, 6(4), 598-613.

Edensor, T. (2002). National Identity, Popular Culture and Everyday Life. Oxford: Berg Publishers.

Eder, K. (2009). A Theory of Collective Identity. Making Sense of the Debate on a "European Identity". European Journal of Social Theory, 12(4), 427-447.

European Commission, (2018). European Heritage Label, Web Site of the European Commission. Retrieved from https://ec.europa.eu/programmes/creativeeurope/actions/heritage-label_en

European Commission, (2010). Proposal for a Decision of the European Parliament and of the Council Establishing a European Union Action for the European Heritage Label. COM(2010) 76 final, 2010/0044 (COD). Brussels: European Commission.

European Communities, (1973, December 12). Declaration of European Identity. Bulletin of the European Communities.

European Parliament, (2011). Decision no 1194/2011/EU of the European Parliament and of the Council of 16 November 2011 Establishing a European Union Action for the European Heritage Label. Official Journal of the European Union L 303, $1-9$.

Fairclough, N. (1995). Media Discourse. London: Edward Arnold. 
Fairclough, N. (2001). Language and Power (2nd ed.). Harlow: Longman.

Fairclough, N. (2003). Discourse and Social Change (reprint). Cambridge: Polity Press.

Fox, J. \& Miller-Idriss, C. (2008). Everyday nationhood. Ethnicities, 8(4), 536-576.

Foucault, M. (1981). The History of Sexuality: Vol. 1, An introduction. (R. Hurley, Trans.) Harmondsworth: Penguin.

Foucault, M. (1991). Politics and the study of discourse. In G., Burchell, C, Gordon \& P. Miller (Eds.), The Foucault Effect: Studies in governmentality. With two lectures by and an interview with Michel Foucault (pp. 53-72). Hemel Hempstead: Harvester Wheatsheaf.

Hall, S. (1997). The Spectacle of the 'Other'. In S. Hall (Ed.), Representation. Cultural Representations and Signifying Practices (pp. 225-279). London: Sage Publications.

Harrison, R. (2013). Heritage: critical approaches. London: Routledge.

Hepp, A., Elsler, M., Lingenberg, S., Mollen, A., Möller, J. \& Offerhaus, A. (2016). The Communicative Construction of Europe. Cultures of Political Discourse, Public Sphere and the Euro Crisis. Basingstoke, Hampshire: Palgrave Macmillan.

Ifversen, J. (2002). Europe and European culture - a conceptual analysis. European Societies, 4(1), 1-26.

Jenkins, R. (2008). The Ambiguity of Europe: 'Identity crisis' or 'situation normal'?. European Societies, 10(2), 153-176.

Jones, S. \& Subotić, J. (2011). Fantasies of power: Performing Europeanization on the European periphery. European Journal of Cultural Studies, 14(5), 542-557.

Kaasik-Krogerus, S. (2016). Normative Stories of the Formative Moment. Construction of Estonian National Identity in Postimees during the EU Accession Process (Doctoral dissertation). Helsinki: Unigrafia.

Kantner, C. (2006). Collective Identity as Shared Ethical Self-Understanding. The Case of the Emerging European Identity. European Journal of Social Theory, 9(4), $501-523$.

Karlsson, K. (2010). The Uses of History and the Third Wave of Europeanization. In M. Pakier \& B. Stråth (Eds.), A European Memory? Contested Histories and Politics of Remembrance (pp. 38-55). New York: Berghahn Books.

Kisić, V. (2017). Governing Heritage Dissonance: Promises and Realities of Selected Cultural Policies. European Cultural Foundation. 
Kohli, M. (2000). The Battlegrounds of European identity. European Societies, 2(2), 113-137.

Lähdesmäki, T. (2014). Transnational Heritage in the Making. Strategies for Narrating Cultural Heritage as European in the Intergovernmental Initiative of the European Heritage Label. Ethnologica Europaea, 44(1), 75-93.

Lähdesmäki, T. (2017). Politics of affect in the EU heritage policy discourse: an analysis of promotional videos of sites awarded with the European Heritage Label. International Journal of Heritage Studies, 23(8), 709-722.

Lähdesmäki, T. \& Mäkinen, K. (2019). The 'European Significance’ of Heritage: Politics of Scale in EU Heritage Policy Discourse. In T. Lähdesmäki, S. Thomas \& Y. Zhu (Eds.), Politics of Scale: New Directions in Critical Heritage Studies (pp. 36-49). New York: Berghahn Books.

Levitt, P. (2015). Artifacts and allegiances: how museums put the nation and the world on display. Oakland, California: University of California Press.

Madianou, M. (2005). Mediating the Nation. News, Audiences and the Politics of Identity. London: UCL Press.

Medrano, J. D. \& Gutiérrez, P. (2001). Nested identities: national and European identity in Spain. Ethnic and Racial Studies, 24(5), 753-778.

Petersson, B. \& Hellström, A. (2003). The return of the kings. Temporality in the construction of EU identity. European Societies, 5(3), 235-252.

Raik, K. (2003). Democratic Politics or the Implementation of Inevitabilities? Estonia's Democracy and Integration into the European Union (Doctoral dissertation). Tartu: Tartu University Press.

Reading, A. (2014). Making Feminist Heritage Work: Gender and Heritage. In E. Waterton \& S. Watson (Eds.), The Companion to Contemporary Heritage Research (pp. 397-413). Basingstoke: Palgrave Macmillan.

Risse, T. (2003). The Euro between national and European identity. Journal of European Public Policy, 10(4), 487-505.

Rose, G. (2016). Visual methodologies: An introduction to researching with visual materials (4th ed.). London: SAGE Publications Ltd.

Rosie, M., Petersoo, P., MacInnes, J., Condor, S. \& Kennedy, J. (2006). Mediating Which Nation? Citizenship and National Identities in the British Press. Social Semiotics, 16(2), 327-344. 
Sassatelli, M. (2002). Imagined Europe. The Shaping of a European Cultural Identity through EU Cultural Policy. European Journal of Social Theory, 5(4), 435-451.

Sassatelli, M. (2008). The European Cultural Space in the European Cities of Culture. European Societies, 10(2), 225-245.

Scalise, G. (2015). The Narrative Construction of European Identity. Meanings of Europe “from below”. European Societies, 17(4), 593-614.

Schlesinger, P. (2000). The Nation and Communicative Space. In H. Tumber (Ed.), Media Power, Professionals and Politics (pp. 99-115). London: Routledge.

Smith, L. (2006). Uses of heritage. London: Routledge.

Smith, L. (2008). Heritage, Gender and Identity. In B. Graham \& P. Howard (Eds.), The Ashgate Research Companion to Heritage and Identity (pp. 159-178). Farnham: Ashgate.

Smith, L. (2012, October 5). Discourses of heritage: implications for archaeological community practice. Nuevo Mundo. Retrieved from https://journals.openedition.org/nuevomundo/64148

Trouillot, M. (1995). Silencing the Past: Power and the Production of History. Boston, Mass: Beacon Press.

Vendil, C. (2000). The Belovezha Accords and Beyond: Delineating the Russian State. Stockholm: Defense Research Establishment.

Waterton, E. \& Smith, L. (2009). There is no such thing as heritage. In E. Waterton \& L. Smith (Eds.), Taking Archaeology out of Heritage (pp. 10-27). Cambridge: Cambridge Scholars Publishing.

Waterton, E. \& Watson, S. (2013). Framing theory: towards a critical imagination in heritage studies. International Journal of Heritage Studies, 19(6), 546-561.

\section{Analysed promotional Videos}

Krapina Neanderthal Site, Croatia

The Heart of Ancient Athens, Greece

Archaeological Park Carnuntum, Austria

Leipzig’s Musical Heritage Sites, Germany

Abbey of Cluny, France

Olomouc Premyslid Castle and Archdiocesan Museum, Czech Republic

Archive of the Crown of Aragon, Barcelona, Spain

Great Guild Hall, Tallinn, Estonia 
Sagres Promontory, Portugal

General Library of the University of Coimbra, Portugal

The Imperial Palace, Vienna, Austria

Union of Lublin, Poland

Münster and Osnabrück - Sites of the Peace of Westphalia, Germany

The May 3, 1791 Constitution, Warsaw, Poland

Historic Ensemble of the University of Tartu, Estonia

Hambach Castle, Germany

Dohány Street Synagogue Complex, Hungary

Fort Cadine, Trento, Italy

Charter of Law of Abolition of the Death Penalty, Lisbon, Portugal

Liszt Ferenc Academy of Music, Budapest, Hungary

Mundaneum, Mons, Belgium

Peace Palace, The Hague, the Netherlands

Javorca Church, Slovenia

Residencia de Estudiantes, Madrid, Spain

World War I Eastern Front Cemetery No. 123, Łużna - Pustki, Poland

Kaunas of 1919-1940, Lithuania

Camp Westerbork, the Netherlands

Former Natzweiler concentration camp and its satellite camps, France - Germany

Franja Partisan Hospital, Slovenia

Sighet Memorial, Romania

European District of Strasbourg, France

Robert Schuman's House, Scy-Chazelles, France

Bois du Cazier, Marcinelle, Belgium

Museo Casa Alcide De Gasperi, Pieve Tesino, Italy

The historic Gdańsk Shipyard, Poland

Village of Schengen, Schengen, Luxembourg

Pan-European Picnic Memorial Park, Sopron, Hungary

Maastricht Treaty, Netherlands 